\title{
Role of Federal Government in Managing Conflicts: Somalia
}

\author{
Dr.Kalsoom Bibi Sumra, \\ Assistant Professor, \\ Centre for Policy Studies CIIT (COMSATS), Islamabad.
}

\author{
Abdalgani Aid Almi, Visiting Faculty, \\ Department of Politics and International Relations \\ International Islamic University, Islamabad.
}

\begin{abstract}
This study is undertaken to critically underline the role of government in managing the conflicts, most notably the federal government of Somalia. The undergone research also discusses the prolonged Somali conflict and options for the conflict resolutions with the available roles for the federal government of Somalia during any conflict. The study finds that the previous conflict resolutions of Somalia were unsuccessful as most of the conflicts exist till today. The role of federal government is limited to the Somali peace processes and conferences with the ethnic motivated perceptions. As a result, the study concludes that the federal government of Somalia is perceived by the public as involved in the conflicts. Thus, in order to eliminate the prolonged Somali conflict, it is suggested to formulate strong federal agencies to prevent any possible conflict in future, besides employing community based conflict resolution mechanisms.
\end{abstract}

Keywords:- Somalia, Conflict Resolution and Management, Role of Government in Conflicts, Somalian Conflict.

\section{INTRODUCTION}

Conflicts around the world have existed since the humans came to earth, to survive they used to fight and defend themselves, it is an expression of inherent violence of existence, todays conflicts among the nations and ethnic groups are merely a symbolic resume of humanity's precivilization struggle to survive, while every technological advancement within the society came a correspondent change to warfare (Kruger, 2015).

Organization for Social Science Research in Eastern and Southern Africa of OSSRES stated in its report that in 1990s alone, many deadly conflicts have raged in different parts of Africa, "watched by the continent, horrified but powerless to act" (Ali, 2004). The presidents of Kenya and Sudan have been once indicted by the international criminal court of justice, the newest nation in the continent of South Sudan is muddy with conflicts. From Libya, Nigeria to Somalia Islamic militants hold a large swath in their thrall (Cowell, 2014). This image of a continent in turmoil with a volcanic conflict, presents an un-imaginable threat to the human experience and prosperity of African continent.

Somalia is not exceptional, while looking back the history of Somalia, one might find that since its independence in $1960^{\text {th }}$, it has witnessed a constant conflicts, with many conflict resolution process that have brought less peace and stability to the country. Moreover,
Somali Republic came into existence in $1^{\text {st }}$ Juley, 1960, when the two entities of Italian Somaliland and British Somaliland were unified, after nine years of union, a bloodless coup d'état has overthrown the democratically elected government and continued to rule out the country since then.

First half of 1980s, Somalia has witnessed political chaos and guerrilla wars, the fights were between the dictatorial regime and national movements, which their aim was to overthrow the military rule. The main movements were; United Somali Congress (USC), Somali National Movement (SNM), Somali Salvation Democratic Front (SSDF), and Somali Patriotic Movement (SPM) (Harper, 2012). In 1991 These movements have won to overthrow the Siad barre from the rule and decades of civil war, droughts and lawless have started. Moreover, from the year of 1991 up to 2004, when Transitional Federal Governmen was established in Djibouti, Somalia was considered to be ungoverned and chaos territory.

However, after a long reconciliation and peace processes, Somalia got an effective Federal Government and acceptable by the world in 2013. Since then the government exercised its legitimacy. Yet, conflicts have continued and and large portion of Somali territory is ruled by tribal warlords and extremist groups, such as; AlShabaab. Thus, this research paper will underline the role of FGS in managing this conflicts.

\section{LITERATURE REVIEW}

The term "conflict" is an active disagreement between people with opposing opinions and principles as defined in Cambridge dictionary. Conflict is a contest or struggle between people with opposing opinions beliefs, ideas, needs, goals or values (Pia \& Diez , 2007) . Conflict is a natural disagreement resulting from individuals or groups that differ in attitudes, beliefs, values or needs. It might be originated from past rivalries and personally disagreement (J.Hoban, 1992). Conflict arises as a result of misunderstanding, men's superiority complex, failure to compromise interests, ideas, believes and cultures (Olanrewaju, 2013). The term "conflict" is used to describe variety of human activates, specially, activities that concern from misunderstanding to international wars, "The term "conflict" has been used to describe a broad range of human activities including hostility between people to international war" (Manning, 2015). From the above definitions, we construct the understanding that the term "conflict" is 
described as a situation of which two or more than two people pursue opposing interests or gains.

Conflict resolution is the process of addressing and removing of the factors that cause a conflict (Gulrez, 2004). Conflict resolution is the process of dealing with the root causes of a conflict to eliminate and find sustainable solutions to them. According to Katz \& McNulty (1994), Conflict resolution is a process of managing a conflict and negotiating a solution. Conflict resolution is a wide term which indicates that the deep-rooted origins of conflict are addressed and resolved. Conflict resolution is such of a mechanism that where conflicting parts sit together and find out their incompatibility and conflicts by peaceful means (Wani, 2011). Aim of the conflict resolution strategy is identifying the underling source of tension (Manning, 2015). Conflict resolution as peace building, peacemaking and peace keeping includes only peaceful ways and mechanisms to maintain peace and security.

As Katz \& McNulty argued, conflict resolution is understood as a working model that have two elements, conflict management and negotiation. Conflict managents is process to change the emotional negetivity state in a conflict to an emotional state that allows findig out a solution to the conflict, while negotiation is a process of communitation to enabling conflicting parties to reache an agreement with respect to their differences. Conflect management also support the long term of social system and institutional goverments that enhance governance, law, economic stability and security. Osaghae stated that there is a sharp distiniction between conflict resolution and conflict management, according to him resolution implies to once and for all handling of conflicts, while managing implies that conflict cannt be handled in one step.

Conflict previntion is the object of a braode range of policies and initiatives which its objective is to avoid the conflic escalation of a dispute. Conflict prevention includes; monitering or intervening a violent conflict before it outbreaks, creating techniques that detect early warning signs, using planed cooperation during humeniterien assistance to prevent outbrak of any conflict or institutionalizing the idea of preventing conflict at regional bases (sais-jhu.edu). controling and managing conflict before it ends into violence, which is more costely, both in human and financial means, than trying to resolve once it occurred. Controling the escalition or re-escalation of a violent conflict is what conflict prevention stands for (Jeong, 2000).

Conflict resolutions differ from one community to another and from one conflict to another, scholers have identified certain tools and methods of conflict resolution which are; avoidence, negotiotion and its different forms of good offices and mediation, conciliation commissions and arbitration etc (Boulding, 1964).
In africa, Socio-political setting that most of conflict resolutions mechanisams use in the continent are costomery system, as long as they are part of the sociaty's tradition, most commonly traditional mechanisams of conflict resolution have the ability and strength to resolve the conflict in a peaceful way, it is also long lasting and it tie up the social structure as it was. In Somalia, traditional clan elders are a main source of conflict mediation, clan-based costemary law works as the basis for negotioted settlement, and clan-based blood payments work as deterent to armed conflects (Wam, 2005).

The act of any party who is/are taking to participate or influence the scenario of any conflict, will be called as a "role". Longman Dictionary has defined the "role" as the way that someone or something is involved in an activity or situation and how much influence they have on it (Longman, n.d.).

\section{METHODOLOGY}

The overall aim of the study is to assess and analyze the role of central government in managing conflicts in Somalia, also to assess the options of conflict resolution and what can be learnt from the previous resolutions. Moreover. The data which is collected through structured Interviews is analyzed on SPSS. The study adopts descriptive design as it is more suitable to the exploratory researches.

\section{$>$ Analytical Framework}

Analytical framework is a structure that a researcher believes will best explain the natural progress of a phenomenon to be studied (Camp, 2001). It is the researcher's explanation of the way that the research problem is explored, while in a statistical perspective, it describes the connectivity of main concepts of the research (Adom, Hussien, \& Agyem, 2018). By analyzing and explaining, one can relate it to the questions of the research. Furthermore, interpretation is a process of making sense of something to draw conclusions and formulate findings (Hart, 2005).

The Longman Dictionary has defined the "role" as the way that someone or something is involved in an activity or situation and how much influence they have on it (Longman, n.d.). Egelind have summarized the role of a government and a third part in an internal conflict as a facilitator or mediator (Egeland, 1999). The manner in which federal government follows greatly influences the conflict resolution in Somalia. There are five major roles that the federal government can play as a third party and each role have its own sequences. Some may lead to the elimination of the conflict while others might fuel the conflict and cause the long-lasting of the conflicts. These five roles are; being force to conflict ending, mediating, facilitating, aligning with one part or having no role at all. 
Conflict in all its forms poses a serious threat to the humankind. Moreover, conflict management and resolutions take different shapes with a variety of outcomes that determine its success or failure. Role that a government undertake is based on the kind of the conflict, while previous conflict resolution outcomes influence the action that might be undertaken.
However, the data is analyzed in a way that allows the researcher to answer the research questions; firstly, previous conflict resolutions are analyzed. Secondly, the role of the federal government is analyzed to formulate a better mechanism for the resolution or management of the Somali conflicts.

\section{ANALYSIS AND MAIN FINDINGS}

\section{A. Analysis}

Data were analyzed through SPSS software, and it was categorized into three categories, first of all, demographics of the participants is shown. Secondly, data related to the previous conflict resolution were analyzed. Thirdly, the roles of Federal Government are analyzed.

\section{Demographics}

\begin{tabular}{|c|c|c|c|}
\hline \multicolumn{2}{|c|}{ Demographics } & \multirow{2}{*}{$\frac{\text { Frequency }}{84}$} & \multirow{2}{*}{$\frac{\text { Percent }}{83.2}$} \\
\hline Gender & Male & & \\
\hline & Female & 17 & 16.8 \\
\hline & Total & 101 & 100.0 \\
\hline \multirow[t]{4}{*}{ Age } & $20-29$ & 79 & 78.2 \\
\hline & $30-39$ & 16 & 15.8 \\
\hline & 40-\&-above & 6 & 5.9 \\
\hline & Total & 101 & 100.0 \\
\hline \multirow[t]{3}{*}{ Country } & Somalia & 75 & 74.3 \\
\hline & Somaliland & 26 & 25.7 \\
\hline & Total & 101 & 100.0 \\
\hline \multirow[t]{4}{*}{ State } & Somaliland & 40 & 39.6 \\
\hline & Puntland & 38 & 37.6 \\
\hline & South-Central & 23 & 22.8 \\
\hline & Total & 101 & 100 \\
\hline
\end{tabular}

\begin{tabular}{|c|c|c|c|}
\hline Region & City & Frequency & Percent \\
\hline Awdal & Borama & 3 & 3.0 \\
\hline Bari & Bosaso, Qardho & 19 & 18.8 \\
\hline Central-Shabeele & Jowhar & 1 & 1.0 \\
\hline Galgaduud & Dhusomareb & 1 & 1.0 \\
\hline Gedo & Beledxawo & 1 & 1.0 \\
\hline Hiiraan & Baladwane,Jowhar & 3 & 3.0 \\
\hline Lower-Juba & Kismayo & 2 & 2.0 \\
\hline Lower-Shabeele & Marka & 1 & 1.0 \\
\hline Maroodijeex & Hargeisa, Gabilay & 30 & 29.7 \\
\hline Mogadishu & Mogadhishu & 11 & 10.9 \\
\hline Mudug & Galkayo, C/waq & 11 & 10.9 \\
\hline Nugaal & Garowe & 5 & 5.0 \\
\hline Saaxil & Berbera & 1 & 1.0 \\
\hline Sanaag & Badhan, Erigabo & 6 & 5.9 \\
\hline Sool & Lasanod & 2 & 2.0 \\
\hline Togdheer & Burao & 4 & 4.0 \\
\hline Total & & 101 & 100.0 \\
\hline
\end{tabular}

Table 1:- Demographic profile

This table presents the demographic details. The result shows that $83 \%$ of our respondents are male, almost $17 \%$ of female. $78 \%$ of the participants are aged between 20-29. Moreover, Despite the fact that all the respondents were from the territory that is recognized internationally as Somalia, hence a $25.7 \%$ of the participants stated Somaliland as an independent country, while $74 \%$ stated Somalia.

Region and City profile of the respondents are also shown on above table of $4-1$. About $30 \%$ of the study participants are from Maroodijeex region, almost $19 \%$ were from Bari region and near to $11 \%$ were from Mugadishu region and the rest are clear on the table. 
Options of Conflict Resolution

\begin{tabular}{|c|c|c|c|c|}
\hline \multicolumn{5}{|c|}{ Successfulness of Past Resolutions } \\
\hline & Somaliland & Puntland & South-central & Total \\
\hline Yes & $7.5 \%$ & $28.9 \%$ & $21.7 \%$ & $18.8 \%$ \\
\hline No & $92.5 \%$ & $71.1 \%$ & $78.3 \%$ & $81.2 \%$ \\
\hline Total & $100 \%$ & $100 \%$ & $100 \%$ & $100 \%$ \\
\hline \multicolumn{5}{|c|}{ wrongly interpretation of Past Resolutions } \\
\hline & Somaliland & Puntland & South-central & Total \\
\hline Yes & $95 \%$ & $81.6 \%$ & $91.3 \%$ & $89.1 \%$ \\
\hline No & $5 \%$ & $18.4 \%$ & $8.7 \%$ & $10.9 \%$ \\
\hline Total & $100 \%$ & $100 \%$ & $100 \%$ & $100 \%$ \\
\hline \multicolumn{5}{|c|}{ Helpfulness of Previous Resolutions } \\
\hline & Somaliland & Puntland & South-central & Total \\
\hline $\begin{array}{l}\text { Resolutions were helpful and most of the } \\
\text { conflicts are resolved }\end{array}$ & $15 \%$ & $44.7 \%$ & $34.8 \%$ & $30.7 \%$ \\
\hline $\begin{array}{l}\text { Resolutions were not helpful and most of the } \\
\text { conflicts still exist }\end{array}$ & $85 \%$ & $55.3 \%$ & $65.2 \%$ & $69.3 \%$ \\
\hline Total & $100 \%$ & $100 \%$ & $100 \%$ & $100 \%$ \\
\hline \multicolumn{5}{|c|}{ Mechanism for Better Conflict Management or Resolution } \\
\hline & Somaliland & Puntland & South-central & Total \\
\hline Modern conflict resolutions mechanism & $27.5 \%$ & $39.5 \%$ & $30.4 \%$ & $32.7 \%$ \\
\hline Customary and traditional way & $72.5 \%$ & $60.5 \%$ & $69.6 \%$ & 67.3 \\
\hline Total & $100 \%$ & $100 \%$ & $100 \%$ & $100 \%$ \\
\hline
\end{tabular}

Table 2:- Conflict Resolutions

The table of $4-5$ reveals $81.2 \%$ respondents in country-wide are on the view that conflict resolutions are adapted successfully while only $18.8 \%$ assume that resolutions were adapted successfully. $89.1 \%$ have chosen that resolutions were interpreted wrongly and the rest $10.1 \%$ stated that resolutions were not interpreted wrongly. However, there is a unique similarity among the three region's participants.

Also the table shows us that $69.3 \%$ of the all the participants have stated that the resolutions were not helpful and most of the conflicts exist, only $30.7 \%$ stated that resolutions were helpful and conflicts are resolved. Moreover, in region-wise analysis we will notice that the respondents are quiet near to each other, $55.3 \%$ of respondents from Puntland stated that the resolutions were not helpful while only $44.7 \%$ have chosen that resolutions were helpful.

$67.3 \%$ of country-wide participants are on the of traditional conflict resolution mechanisms as a better mechanism for Somali conflict resolution, 32.7\% have stated that modern conflict resolution mechanisms will be better for Somali resolutions.

\begin{tabular}{|c|c|c|c|c|}
\hline \multicolumn{5}{|c|}{ Role of Federal Government in resolving conflicts } \\
\hline & Somaliland & Puntland & South-central & Total \\
\hline Positive role, that it solves the most & $12.5 \%$ & $36.8 \%$ & $43.5 \%$ & $28.7 \%$ \\
\hline $\begin{array}{l}\text { Negative role, that it doesn't solve the } \\
\text { most }\end{array}$ & $67.5 \%$ & $31.6 \%$ & $52.2 \%$ & $50.5 \%$ \\
\hline No role & $20 \%$ & $31.6 \%$ & $4.3 \%$ & 20.8 \\
\hline Total & $100 \%$ & $100 \%$ & $100 \%$ & $100 \%$ \\
\hline \multicolumn{5}{|c|}{ Role of federal Government regarding SL / PL conflict } \\
\hline & Somaliland & Puntland & South-central & Total \\
\hline Part of the conflict & $67.5 \%$ & $26.3 \%$ & $21.7 \%$ & $41.6 \%$ \\
\hline Mediator & $5 \%$ & $23.7 \%$ & $17.4 \%$ & 14.9 \\
\hline
\end{tabular}


ISSN No:-2456-2165

\begin{tabular}{|c|c|c|c|c|}
\hline Facilitator & $7 \%$ & $7.9 \%$ & $8.7 \%$ & $7.9 \%$ \\
\hline Force to conflict ending & $7 \%$ & $7.9 \%$ & 0 & $5.9 \%$ \\
\hline No role & $12.5 \%$ & $34.2 \%$ & $52.2 \%$ & $29.7 \%$ \\
\hline Total & $100 \%$ & $100 \%$ & $100 \%$ & $100 \%$ \\
\hline \multicolumn{5}{|c|}{ Weakness of Federal agencies } \\
\hline Yes & Somaliland & Puntland & South-central & Total \\
\hline No & $57.5 \%$ & $65.8 \%$ & $87 \%$ & $67.3 \%$ \\
\hline Total & $42.5 \%$ & $34.2 \%$ & $13 \%$ & $32.7 \%$ \\
\hline
\end{tabular}

Table 3:- Roles of Federal Government

The table shows that $50.5 \%$ of all the participants have stated that the Federal government plays a negative role regarding Somali conflict resolutions, $28.7 \%$ also expressed that it plays a positive role while only $20.8 \%$ stated it have no role at all. Moreover, majority (36.8\%) of respondents from Puntland stated that the government played a positive role regarding the Somali conflict resolutions while $31.6 \%$ have chosen that it played a negative role and similar number stated it have no role, this might be because of ethnic affiliation of Puntland inhabitants with the current head of federal government. Other two regions have similar opinions that majority of their respondents stated the negative role of the federal government.

The table also reveals the role of federal government towards Somaliland-Puntland conflict, $41.6 \%$ in overall responses has shown that government played as a part of the conflict, while $29.7 \%$ of the respondents stated it had no role at all, $14.9 \%$ stated it played the role of mediator, $7.9 \%$ expressed that it played a facilitator role while only $5.9 \%$ stated it was a force to conflict ending.

However, majority of Somaliland respondents stated that the federal government was part of the conflict, this might be due to their idea of separation and looking the rest of Somalia as a united neighboring country. Majority of Puntland (34.2\%) and South-central $(52.2 \%)$ respondents have chosen "no role" as the main role of the federal government towards the Somaliland-Puntland conflict

Weakness of federal agencies is mentioned by $67.3 \%$ of the respondents as main reason of conflict SomalilandPuntland conflict, while only $32.7 \%$ stated the opposite, that weakness of federal agencies is not responsible on the conflict existence.

\section{Main Findings}

The study found that the Somali Conflict resolutions were not adapted successful. $81.2 \%$ of the total participants were on the view of this "passed resolutions were not adapted successfully". This indicates that almost all the resolutions have failed since now.
It was found that Somali conflict resolutions were interpreted wrongly, wither by the implementing institutions or by the public themselves. $91.3 \%$ of all the respondents of the study have stated that previous conflict resolutions were wrongly interpreted.

The study has found that previous Somali conflict resolutions were not helpful to eliminate the conflicts in Somalia since most of the conflicts exist till today. A majority $(69.3 \%)$ of the respondents have stated this "previous conflict resolutions were not helpful and most of the conflicts exist"

It is found by the study that federal government of Somalia which had the options to play a positive, negative or no role at all have played a negative role regarding the Somali conflict resolutions. It does not solve or manage most of the conflicts, $50.5 \%$ of the participants are on the view that the federal government have took a negative role in overall Somali conflict resolution efforts.

The study found that the federal government of Somali was involved some of the conflicts that it supposed to solve or mange it. $41.6 \%$ of the study participants are on the view that the federal government of Somalia have aligned with one of the two parts that fought against each other. In illustration, Somaliland and Puntland.

It was found that a weakness regarding federal agencies of conflict resolution or management exist. $67.3 \%$ of the total participants stated that Somaliland-Puntland conflict exist due to weakness of federal agencies, which means that federal agencies does not have the power to solve such kind of conflict that took place its internationally recognized territory.

The study found that a community based traditional and customary way of conflict resolution will be better in terms of Somali conflict resolutions or management. $67.3 \%$ of the study participants have stated that costmary and traditional way of conflict resolution can eliminate Somali ethnic wars. Thus, it is emphasized by the participants the need of customary and traditional elders to participate or lead the Somali resolutions. 


\section{CONCLUSION AND RECOMMENDATIONS}

\section{$>$ Conclusion}

Role that federal government play and the perception of previous conflict resolutions will always influence any further resolutions. Successfulness of past resolutions promote the hope of people for the current or upcoming resolutions and they don't surrender, also the right interpretation of previous Somali resolutions by the government institutions, community elders or the public themselves will promote peaceful coexistence.

Centrality of community based traditional way of conflict resolution is widely believed among the Somalis. Thus, it must be tried a different method of conflict resolution that emphasize the strength of traditional leaders as conflict resolutions leader. Since their involvement were very less and Somali community have strong faith over clan elders it must be encouraged that clan elders should lead the upcoming resolutions.

There must be follow-ups to the Somali conflict resolution efforts, so to prevent misunderstandings that lead to a violent conflict. Conflict resolution is not only ending war but it also includes to form integration and corporation among the conflicted parties to find a long-lasting peace.

The conflict management authorities in Somalia are very fragile that also the federal government system is very young, empowering and strengthening the customary and traditional institution of conflict resolutions and management will play a very prominent role in normalizing.

Finally, the author of this research admits that the study did not cover all the aspects of fundamental Somali conflicts and the role of government in managing it. Thus, suggests further field research in a broader prospective on the Somali conflicts and how the federal government interventions resolve or mange the Somali conflicts within its territory.

\section{$>$ Recommendation}

The federal government institutions should avoid any kind of skeptical actions that one or more than one of the conflicting parties may preserve it as opposing to its own interests. Otherwise, the federal agency which it is main task was to keep the peaceful co-existence among Somali ethnics will be seen as conflict promoter that plays a negative role in conflict resolutions of its own nation. A very large number of Somalis believe that the federal government plays a negative role. Only by avoiding the actions that create doubts among itself and conflicting parties, this believe can be eradicate.

Further conflict resolution processes or national conferences should also consider the partition of colonials and African Union agreement of Uti-possidetis since some recent conflicts, such Somaliland-Puntland conflicts are caused by the state formation of colonials that started in the 1940 s to 1950 s with the decolonization process.
A committee or enforcing party should be found for further resolutions, so that to eliminate the unsuccessfulness of resolutions and also the wrongly interpretations. Furthermore, helpfulness of any resolution is a key figure for further successful resolutions that the Somali community will largely be satisfied with Strong federal agencies must be created so that they may interfere any conflict by means of facilitating or as an enforcing party that compels the parties to stop the fighting. Also, there is much varieties of political ideologies that can lead to a break of a conflict in any time. So the need of strong federal institutions is very needed to create more acceptable ideology to strength the peaceful co-existence.

Wrongly interpretations of previous conflict resolutions and also the unsuccessfulness of its agendas causes the loss of hope of Somali people which at the end leads the complication of further resolutions. So, the study recommends that the government must establish a committee to make check-ups on the righteous interpretations and successfulness of past resolutions to bring sustainable peace in Somalia.

A community based traditional and customary way of conflict resolutions must be employed for further conflict management and resolutions, so that to completely eliminate Somali ethnic conflicts, most of the previous conflict resolutions were hosted by foreign countries and in some way influenced the outcomes.

Weakness of federal agencies exist and this is one way or another responsible on conflict existence in Somalia. Thus, the study recommends that the federal government should strengthens its agencies to reduce the conflicts and eliminate it at the near future.

\section{REFERENCES}

[1]. Ali, M. (2004, December 1). Conflict in Africa: an overview: Key note speech, in the proceedings of the international conference on African conflicts: management, resolution, post conflict recovery and development. Addis ababa: OSSREA.

[2]. Boulding, K. E. (1964). Conflict and Defence: A General theory. New York: Harper \& Brothers.

[3]. Cowell, A. (2014, november ). LETTER FROM EUROPE:Looking Past Africa's Turmoil. nytimes.

[4]. Gulrez, M. (2004). Conflict Transformation in West Asia - Oslo Process and Beyond: The Transcend Perspective. New Delhi: Uppal PublishingHouse.

[5]. Harper, M. (2012). Getting Somalia wrong?: Faith, war and hope in a shattered state. London: Zed Books Ltd.

[6]. J.Hoban, D. (1992). concervative Technology Information Center (CTIC). Retrieved from concervative Technology Information Center (CTIC): http://www.ctic.purdue.edu/media/files/Managing\%20 Conflict.pdf

[7]. Jeong, H.-W. (2000). Peace and conflict studies: An introduction. Routledge. 
[8]. Kruger, R. (2015, october). Social Darwinism, class conflict, and war: a call for new tools of analysis for the contemporary moment.

[9]. Manning, C. (2015). Defining Conflict Resolution. Melbourne. Retrieved December 12, 2018, from http://www.carolynmanningconsultingservices.com.au /index.php/download_file/view/74/283/

[10]. Olanrewaju, I. (2013). The conceptual definations of peace and conflict. Redings in Peace studies and Conflict Resolution, 6-14.

[11]. Pia, E., \& Diez , T. (2007). Conflict and Human Rights: A Theoretical Framework . Brimingham : University of Birmingham.

[12]. sais-jhu.edu. (n.d.). Retrieved from sais-jhu.edu: https://www.sais-jhu.edu/content/conflict-prevention

[13]. Wam, P. E. (2005). Conflict in Somalia: Drivers and Dynamics. Worldbank.

[14]. Wani, H. A. (2011). Understanding Conflict Resolution. Centre for Promoting Ideas, USA, 1, No.2. 